\title{
Penapisan Bakteri Filosfer Penghasil Senyawa Bioaktif Anti Xanthomonas oryzae pv. oryzae Penyebab Penyakit Hawar Daun Bakteri pada Padi
}

\author{
Rina Nurfitriani ${ }^{1}$, Ni Putu Ratna Ayu Krishanti ${ }^{2}$, Alina Akhdiya ${ }^{3}$, Aris Tri Wahyudi ${ }^{*}$ \\ ${ }^{I}$ Departemen Biologi, Fakultas MIPA Institut Pertanian Bogor \\ Jl. Raya Darmaga Kampus IPB Darmaga Bogor 16680, Jawa Barat, Indonesia \\ ${ }^{2}$ Pusat Penelitian Biomaterial - Lembaga Ilmu Pengetahuan Indonesia. \\ Jl. Raya Bogor Km 46, Cibinong-Bogor 16192 \\ ${ }^{3}$ Balai Besar Litbang Bioteknologi dan Sumber Daya Genetik Pertanian. \\ Jl. Tentara Pelajar 3A, Cimanggu-Bogor 16111
}

Diterima 20 April 2016/Disetujui 13 Mei 2016

\begin{abstract}
Bacterial leaf blight caused by Xanthomonas oryzae pv. oryzae (Xoo) is one of the important diseases in rice crops in Indonesia. The disease is difficult to be controlled since it attacks the rice plant at different growth stages such as tillering, flowering and ripening. One of the alternatives that could be used to control the disease is by using phyllosphere bacteria as the biocontrol agents. This study aims to isolate, characterize and screen the rice phyllosphere bacteria producing bioactive compounds against Xoo. Phyllosphere bacteria isolated from healthy leaves of rice var. Ciherang by using 4 different media obtained 285 bacterial isolates which were consisted of the 65 isolates of King's B agar, 86 isolates of Nutrient agar, 81 isolates of Luria-Bertani agar, and 53 isolates of Trypticase Soy agar media. Antagonist test using double layer method showed 58 isolates of phyllosphere bacteria produced bioactive compounds that inhibited the growth of Xoo. Pathogenicity test agaist rice leaf revealed 18 bacterial isolates did not perform their potencies as pathogenic bacteria. Among the 18 non-phytopathogenic bacterial isolates, 14 isolates belong to Gram-positive bacteria and 4 isolates belong to Gram-negative bacteria. Five isolates among Gram positive bacteria were predicted as Bacillus genera.
\end{abstract}

Keywords: Bacterial leaf blight, bioactive compound, phyllosphere bacteria, Xanthomonas oryzae pv. oryzae (Xoo).

\section{PENDAHULUAN}

Padi merupakan komoditas pangan yang sangat penting di Indonesia. Lebih dari $50 \%$ populasi penduduk Indonesia mengkonsumsi padi sebagai makanan pokok. Sebagaimana umumnya negara berkembang, Indonesia menghadapi masalah pertumbuhan jumlah penduduk yang tinggi dan penyediaan bahan pangan pokok yang kurang memadai.

Upaya peningkatan produksi padi nasional terus dilakukan pemerintah, namun berbagai kendala seperti masalah penyakit hawar daun bakteri (HDB) menjadi penghambat upaya tersebut (Hanarida et al. 2007). HDB merupakan penyakit padi paling serius yang disebabkan oleh bakteri

*Penulis korespondensi. E-mail: aristri2011@gmail.com
Xanthomonas oryzae pv. oryzae (Xoo). Di daerah tropis, penyakit HDB menyerang tanaman padi di berbagai wilayah penghasil padi baik pada musim hujan maupun kemarau (Dinh 2008). Penyakit ini menurunkan kemampuan tanaman untuk melakukan proses fotosintesis karena klorofil daun mengalami kerusakan. Apabila hal ini terjadi pada fase generatif maka proses pengisian gabah menjadi kurang sempurna atau bahkan hampa sehingga dapat menyebabkan kehilangan hasil produksi yang lebih banyak (Sudir et al. 2012).

Bakterisida kimia secara rutin umumnya digunakan untuk mengendalikan penyakit HDB di Indonesia. Namun, ketergantungan yang berlebihan pada bakterisida kimia sering menyebabkan pencemaran lingkungan dan meningkatkan resistensi. Selain itu, residu bakterisida pada bulir padi dapat menyebabkan masalah kesehatan pada konsumen. Oleh karena itu, penggunaan agen biokontrol berbasis 
mikroba dapat digunakan sebagai alternatif pengganti untuk bakterisida kimia (Hastuti 2012).

Fakta bahwa beberapa senyawa bioaktif mikroba memainkan peranan penting dalam mekanisme biokontrol terhadap patogen tanaman tertentu telah mendorong pengembangan senyawa dan atau mikroba penghasilnya menjadi agen biokontrol untuk penggunaan komersial (Dowling \& O'Gara 1994). Salah satu sumber agen biokontrol penghasil senyawa bioaktif yang dapat menghambat aktivitas Xoo adalah bakteri filosfer. Sebagai agen biokontrol, bakteri filosfer berperan penting dalam perlindungan tanaman dari serangan patogen. Data mengenai keragaman bakteri filosfer asal tanaman padi khususnya di Indonesia terutama yang dapat memproduksi senyawa bioaktif anti Xoo masih sangat terbatas. Oleh karena itu tujuan dari penelitian ini adalah mengisolasi dan menapis bakteri filosfer yang berpotensi sebagai agen biokontrol terhadap patogen penyakit hawar daun bakteri.

\section{BAHAN DAN METODE}

Pengambilan Sampel Daun Padi. Pengambilan sampel dilakukan di daerah persawahan Situgede, Kecamatan Bogor Barat, Kota Bogor. Sampel padi yang diambil merupakan rumpun padi sehat (tidak terkena penyakit HDB) varietas Ciherang berumur 2.5 bulan, yang berasal dari petak padi yang terkena penyakit HDB.

Isolasi Bakteri Filosfer. Satu gram sampel daun padi dipotong-potong berukuran $1 \mathrm{~cm} 2$ dan direndam dalam larutan fisiologis $0,85 \%$ selama \pm 30 menit. Kemudian sampel di-vorteks sehingga didapatkan suspensi. Suspensi bakteri diencerkan hingga 10-6 $\mathrm{sel} / \mathrm{mL}$ dan disebar pada media padat. Sebanyak 100 $\mu 1$ suspensi disebar pada media King's $B$ agar (KBA), nutrient agar (NA), Luria-Bertani agar (LA), dan trypticase soy agar (TSA), kemudian diinkubasi pada suhu ruang selama 24 jam. Koloni-koloni tunggal yang tampak berbeda dipilih untuk dimurnikan pada medium yang sama.

Uji Antagonisme Bakteri Filosfer terhadap Xanthomonas oryzae pv. oryzae. Uji antagonisme in-vitro ini dilakukan menggunakan metode double layer (Lisboa et al. 2006), untuk menyeleksi isolat yang berpotensi menghasilkan senyawa bioaktif yang dapat menghambat pertumbuhan Xoo. Sebanyak $1 \mathrm{ml}(108 \mathrm{cfu} /$ ml) kultur cair bakteri Xoo diinokulasi ke dalam 100 ml LA semi padat kemudian dituang pada permukaan cawan LA masing-masing sebanyak $10 \mathrm{ml}$. Setelah permukaan media LA double layer memadat, kultur bakteri filosfer berumur 24 jam dibiarkan meresap pada potongan kertas cakram Whatman No.2 (diameter
$0,6 \mathrm{~cm})$, kemudian dikering anginkan dan diletakkan di permukaan cawan agar yang telah diinokulasi $\mathrm{XoO}$ tersebut. Biakan diinkubasi selama 24 jam kemudian diamati zona hambat di sekeliling cakram. Indeks Penghambatan (IP) dihitung dengan menggunaan persamaan sebagai berikut:

\section{$\mathrm{IP}=\{$ diameter zona bening $(\mathrm{cm})-$ diameter cakram $(\mathrm{cm})\}$ diameter cakram $(\mathrm{cm})$}

Uji Hipersensitivitas pada Tembakau. Uji hipersensitivitas isolat bakteri terhadap tanaman tembakau dilakukan menurut Zou et al. (2006). Kultur cair isolat bakteri filosfer dengan kerapatan $\pm 108 \mathrm{cfu} / \mathrm{ml}$ dalam kultur cair disuntikkan ke daun tanaman tembakau menggunakan syringe $1 \mathrm{ml}$ (tanpa jarum). Sebagai kontrol positif digunakan Xoo STG 21, sedangkan untuk kontrol negatif digunakan Escherichia coli DH5 $\alpha$ dan akuades steril. Pengamatan gejala penyakit dilakukan hingga 48 jam setelah penyuntikan.

Uji Patogenisitas pada Padi. Benih padi IR64 yang telah disterilisasi permukaannya dengan Natrium-hipoklorit 2\% ditumbuhkan dalam keadaan steril di dalam growth chamber hingga berusia dua minggu. Ujung daun padi selanjutnya digunting dan dicelupkan kedalam suspensi bakteri uji (kerapatan $\pm 108 \mathrm{cfu} / \mathrm{ml}$ ) selama \pm 10 detik. Pengamatan gejala penyakit dilakukan pada 3 dan 14 hari setelah inokulasi (Wahyudi et al., 2011) Uji patogenisitas dinyatakan positifjika bakteri yang diinokulasikan menyebabkan penyakit pada daun padi dan dinyatakan negatif jika bakteri yang diinokulasikan tidak menyebabkan penyakit pada daun padi.

Pewarnaan Gram dan Pewarnaan Endospora. Karakterisasi terbatas isolat-isolat bakteri dilakukan pada 18 isolat bakteri yang tidak bersifat patogenik pada tanaman yang dilakukan dengan teknik pewarnaan Gram. Isolat yang termasuk bakteri Gram positif dan berbentuk batang selanjutnya diamati keberadaan struktur endosporanya menggunakan metode pewarnaan spora (Lay 1994).

\section{HASIL}

Isolasi Bakteri Filosfer. Sebanyak 285 isolat bakteri filosfer berhasil diisolasi dari rumpun padi sehat varietas Ciherang berumur 2.5 bulan asal Situgede, Bogor. Isolasi dengan menggunakan empat media yang berbeda menghasilkan jumlah isolat bakteri yang bervariasi (Gambar 1). Dari media LA diperoleh 81 isolat, dari media NA diperoleh 86 isolat, dari media TSA diperoleh 53 isolat, dan dari media KBA diperoleh 65 isolat. 
Uji Antagonisme Bakteri Filosfer Terhadap Xanthomonas oryzae pv. oryzae. Sebanyak 58 isolat dari 285 isolat yang diperoleh menunjukkan kemampuan dalam menghambat Xoo secara in-vitro. Aktivitas penghambatan tersebut terlihat dari adanya zona bening di sekitar isolat bakteri filosfer yang diuji (Gambar 2).

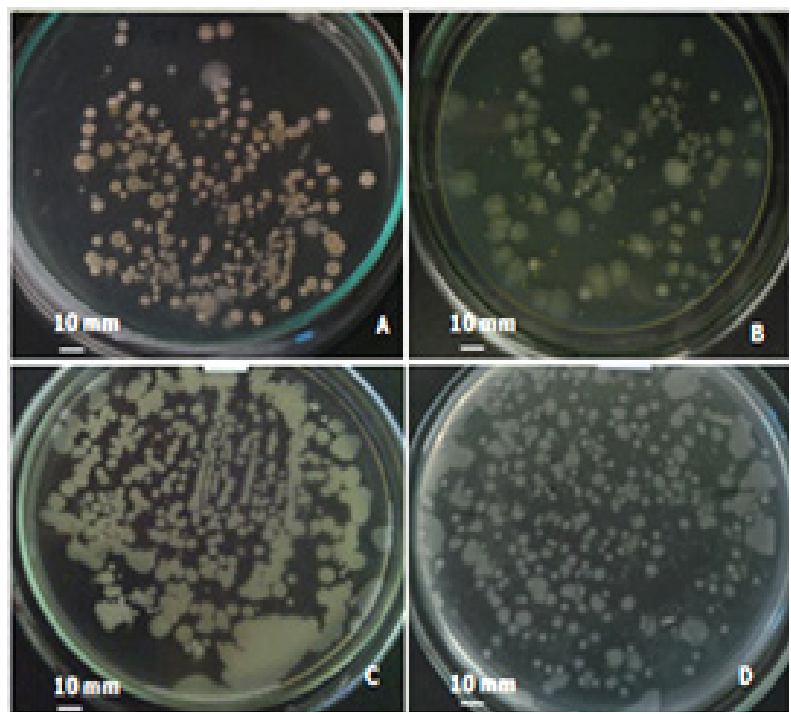

Gambar 1. Koloni - koloni bakteri filosfer padi yang tumbuh pada media KBA (A), NA (B), LA (C), dan TSA (D).

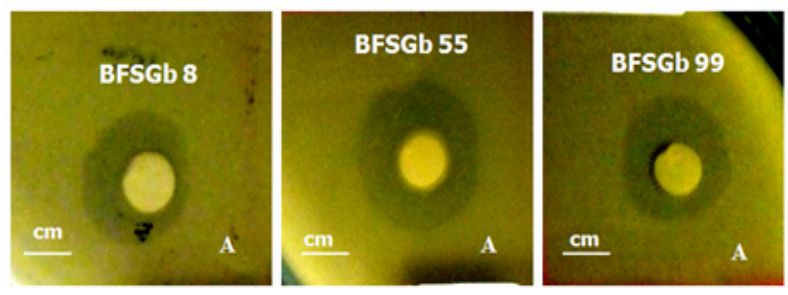

Gambar 2. Zona hambat isolat bakteri BFSGb 8 (A), BFSGb 55 (B), dan BFSGb 99 (C) terhadap Xoo.

Tabel 1. Jumlah isolat bakteri filosfer padi yang mampu menghambat pertumbuhan Xoo dan nilai indeks penghambatannya

\begin{tabular}{cc}
\hline Indeks penghambatan (IP) & Jumlah isolat \\
\hline+++++ & 2 \\
++++ & 3 \\
+++ & 20 \\
++ & 20 \\
+ & 13 \\
\hline
\end{tabular}

Keterangan: $+++++:>2.00$

$$
\begin{aligned}
& +++ \text { : IP } 1.51-2.00 \\
& +++\quad: \text { IP } 1.01-1.50 \\
& ++\quad: \text { IP } 0.51-1.00 \\
& +\quad: \text { IP }<0.50
\end{aligned}
$$

Diantara 58 isolat tersebut, 34\% merupakan isolat yang diisolasi menggunakan media $\mathrm{KBA}, 17 \%$ menggunakan media NA, 29\% menggunakan media LA, dan 19\% menggunakan media TSA (Gambar 3; Tabel 1). Hasil ini menunjukkan bahwa media KBA lebih sesuai untuk media isolasi bakteri filosfer yang bersifat antagonis terhadap Xoo.

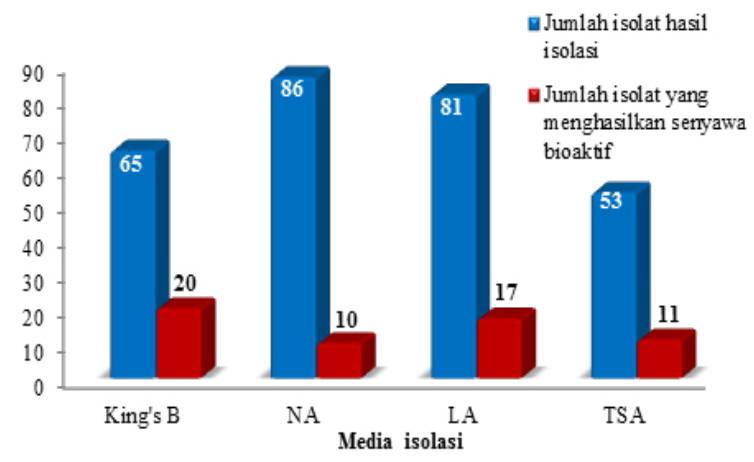

Gambar 3. Perbandingan isolat bakteri filosfer yang diperoleh dengan isolat bakteri filosfer penghasil senyawa bioaktif anti-Xoo.

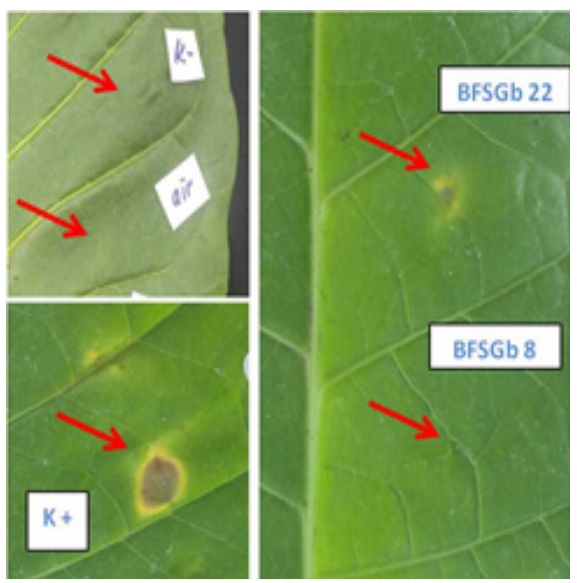

Gambar 4. Hasil uji hipersensitive respon pada daun tembakau dengan akuades steril (Air), E. coli $\mathrm{DH} 5 \alpha$ (K-), Xoo STG $21(\mathrm{~K}+)$, isolat BFSGb 22, dan isolat BFSGb 8. Anak panah menunjukkan bagian daun yang diinokulasi bakteri filosfer.

Uji Hipersensitivitas pada Tembakau. Sebanyak 58 isolat yang bersifat antagonis terhadap Xoo diuji reaksi hypersensitive respon (HR) yang ditimbulkannya pada tembakau. Reaksi HR yang ditimbulkan isolat-isolat bakteri filosfer yang patogenik teramati dengan jelas 48 jam setelah dilakukan infeksi. Reaksi yang sama juga ditunjukkan oleh daun tembakau yang diinokulasi dengan Xoo STG 21. Sebaliknya pada daun yang diinfeksi dengan E. coli DH5 $\alpha$ dan akuades steril (kontrol negatif) tidak menunjukkan reaksi hipersensitif (Gambar 4). $58 \%$ dari total 58 isolat yang bersifat antagonis terhadap Xoo mengakibatkan timbulnya HR pada tanaman tembakau.

Uji Patogenisitas pada Padi. Uji pada tanaman padi menunjukkan 6 dari 24 isolat yang tidak 
menyebabkan reaksi HR pada tembakau ternyata bersifat patogenik pada tanaman padi. Ini berarti bahwa bakteri yang menunjukkan hasil uji HR negatif pada tanaman tembakau tidak menjamin bahwa bakteri tersebut bersifat non patogenik pada semua jenis tanaman (Gambar 5).

Pewarnaan Gram dan Pewarnaan Endospora. Pewarnaan Gram dilakukan untuk identifikasi awal
18 isolat bakteri filosfer terpilih. Hasil yang diperoleh menunjukkan 14 isolat bakteri berwarna ungu atau termasuk kelompok Gram positif, sedangkan 4 sisanya berwarna merah yang menunjukkan kelompok Gram negatif (Tabel 2). Sembilan dari 14 isolat yang bersifat Gram positif memiliki sel berbentuk batang dan 5 isolat (BFSGb 55, 64, 220, 238, dan 266) diantaranya memiliki endospora.

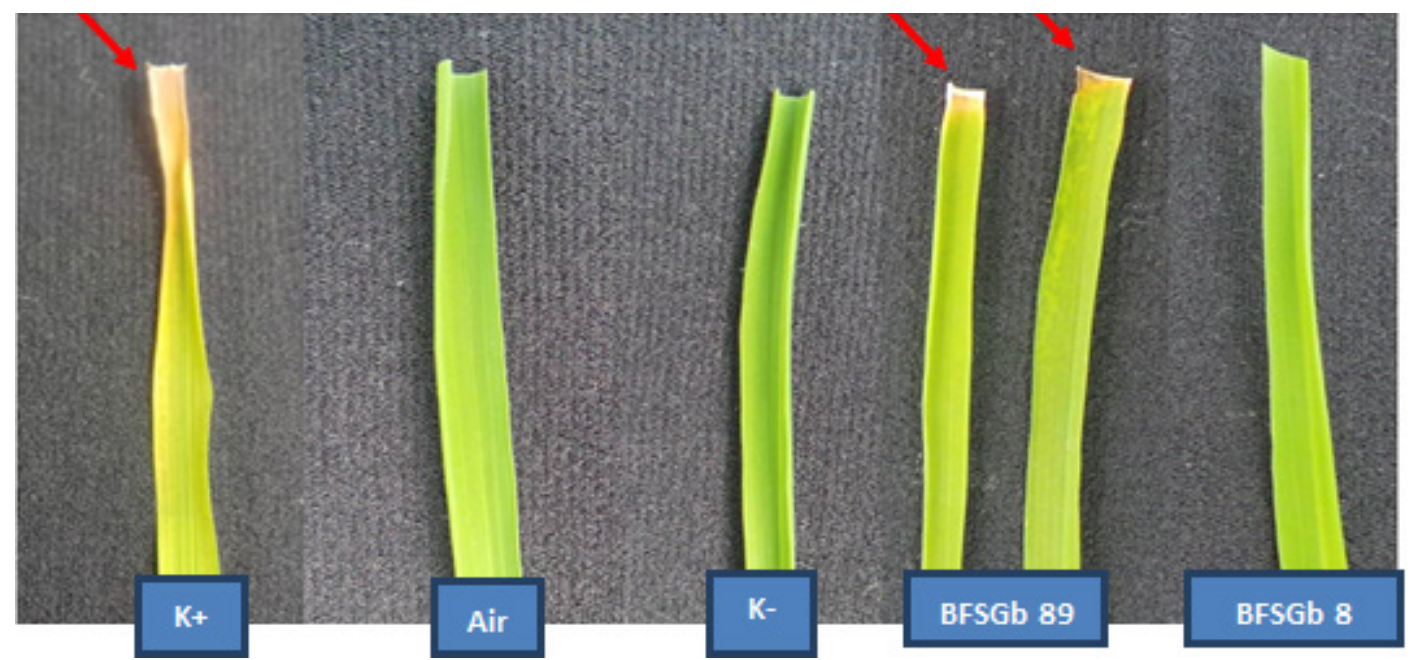

Gambar 5. Tampilan daun padi IR64 umur satu bulan setelah 14 hari dinfeksi dengan Xoo STG 21 (K+), akuades steril (Air), E. coli $\mathrm{DH} 5 \alpha(\mathrm{K}-)$, isolat BFSGb 89, dan isolat BFSGb 8. Anak panah menunjukkan gejala hawar atau nekrotik.

Tabel 2. Reaksi Gram dan keberadaan endospora pada 18 isolat bakteri filosfer non patogenik penghasil senyawa bioaktif anti Xoo

\begin{tabular}{|c|c|c|c|c|c|}
\hline No. & Kode isolat & Jenis Gram & Bentuk sel & Penataan sel & Struktur endospora \\
\hline 1 & BFSGb 8 & Positif & Batang & Berantai dua & - \\
\hline 2 & BFSGb 35 & Positif & Kokus & Tunggal & - \\
\hline 3 & BFSGb 55 & Positif & Batang panjang & Berantai & + \\
\hline 4 & BFSGb 64 & Positif & Batang & Berantai & + \\
\hline 5 & BFSGb 69 & Positif & Batang & Berantai & - \\
\hline 6 & BFSGb 88 & Positif & Kokus & Tunggal & - \\
\hline 7 & BFSGb 95 & Positif & Kokus & Bergerombol & - \\
\hline 8 & BFSGb 99 & Negatif & Batang pendek & Tunggal & - \\
\hline 9 & BFSGb 153 & Negatif & Batang & Tunggal & - \\
\hline 10 & BFSGb 162 & Negatif & Batang & Berantai & - \\
\hline 11 & BFSGb 183 & Positif & Batang & Tunggal & - \\
\hline 12 & BFSGb 185 & Positif & Batang & Tunggal & - \\
\hline 13 & BFSGb 202 & Negatif & Batang panjang & Berantai dua & - \\
\hline 14 & BFSGb 203 & Positif & Kokus & Bergerombol & - \\
\hline 15 & BFSGb 217 & Positif & Kokus & Tunggal & - \\
\hline 16 & BFSGb 220 & Positif & Batang & Berantai & + \\
\hline 17 & BFSGb 238 & Positif & Batang & Tunggal & + \\
\hline 18 & BFSGb 266 & Positif & Batang & Berantai & + \\
\hline
\end{tabular}

Keterangan gambar : $(+)$ terdapat endospora, $(-)$ tidak terdapat endospora. 


\section{PEMBAHASAN}

Bakteri filosfer merupakan bakteri yang hidup di permukaan daun tanaman, untuk mengisolasi bakteri filosfer dibutuhkan media yang sesuai dan mendukung pertumbuhannya. Dibandingkan dengan tiga media isolasi lainnya, jumlah koloni bakteri yang tumbuh pada media NA (86 isolat) relatif lebih banyak dibandingkan dengan dengan jumlah koloni yang tumbuh pada media isolasi lainnya. NA adalah media non-selektif yang umum digunakan untuk menumbuhan bakteri. Tingginya jumlah koloni yang tumbuh pada media NA diduga disebabkan oleh komposisinya yang mampu mendukung pertumbuhan kebanyakan bakteri. Media ini dapat digunakan untuk bakteri yang tidak membutuhkan kondisi khusus (Downes 2001). Jumlah koloni bakteri yang tumbuh pada media LA (81 koloni) tidak jauh berbeda dengan jumlah koloni yang tumbuh pada media NA. Hal ini dapat disebabkan karena LA termasuk media yang bersifat non-selektif dan relatif kaya nutrisi yang umum digunakan untuk pertumbuhan bakteri (Bertani 1951).

Dibandingkan dengan media NA dan LA, jumlah koloni bakteri yang tumbuh pada media TSA (53 koloni) dan jumlah koloni bakteri pada media KBA (65 koloni). Hal ini diduga karena komposisi nutrisi TSA yang relatif lebih sederhana dibandingkan dengan NA dan LA. Media KBA merupakan media isolasi yang relatif paling sederhana komposisi nutrisinya dan umum digunakan untuk isolasi bakteri filosfer. Penggunaan media yang tidak terlalu kaya nutrisi untuk isolasi bakteri filosfer ditujukan untuk menjaring kelompok bakteri yang tumbuh relatif lambat, sesuai dengan kondisi daerah filosfer yang relatif lebih terbatas ketersedian nutrisinya (Lindow \& Brandl 2003).

Keragaman isolat bakteri filosfer yang diperoleh dipengaruhi oleh kondisi lingkungan tempat pengambilan sampel dan jenis sampel yang diambil. Permukaan tanaman mengalami perubahan suhu yang cepat dan kelembaban dalam menanggapi adanya embun dan hujan. Selain itu, ketersediaan nutrisi pada permukaan tanaman juga mempengaruhi keragaman bakteri filosfer (Lindow \& Brandl 2003). Pada umumnya bakteri filosfer dapat menahan stres lingkungan seperti paparan radiasi ultraviolet yang tinggi di permukaan daun. Ketahanan bakteri filosfer terhadap radiasi ultraviolet disebabkan antara lain produksi pigmen merah muda atau oranye atau polisakarida ekstraselular (EPS) yang melindunginya dari radiasi tersebut. EPS dapat juga melindungi bakteri dari keterbatasan air, membantu sel untuk menyesuaikan dengan permukaan daun, dan melindungi dari aktivitas senyawa antibiotik atau antimikroba (Whipps et al. 2008). Selain itu, senyawa antimikroba yang diproduksi oleh beberapa bakteri filosfer dapat juga mempengaruhi keragaman bakteri filosfer (Lindow \& Brandl 2003). Morris dan Kinkel (2002) menyatakan bahwa komunitas mikroba dari filosfer sangat beragam dan bakteri mempunyai kelimpahan dan variasi yang paling tinggi dengan rata-rata berkisar $10^{2}$ sampai $10^{12} \mathrm{sel} / \mathrm{g}$ daun (Thompson et al. 1993; Inacio et al. 2002).

Beberapa bakteri filosfer dapat memroduksi suatu senyawa bioaktif untuk berkompetisi dengan mikroorganisme lain untuk memperoleh ruang dan nutrisi untuk tumbuh (Lindow \& Brandl 2003). Senyawa antimikroba yang dihasilkan oleh suatu bakteri dapat menyebabkan interaksi yang bersifat antagonis antara bakteri penghasil senyawa tersebut dengan mikroba lain di sekitarnya. Keberadaan bakteri patogen tanaman dapat dihambat melalui mekanisme antagonis dari bakteri filosfer sehingga tidak menyebabkan penyakit pada tanaman.

Uji HR dan patogenesitas pada tanaman penting untuk dilakukan terhadap isolat-isolat bakteri yang memiliki potensi sebagai agen biokontrol. Pada habitatnya, bakteri filosfer dalam jumlah yang sedikit dapat tidak berpotensi sebagai patogen, namun dalam jumlah yang sangat banyak bakteri filosfer juga dapat berpotensi sebagai patogen pada tanaman inangnya untuk memperoleh nutrisi. Reaksi HR didefinisikan sebagai program kematian sel yang cepat dan terlokalisasi. Reaksi ini muncul pada tanaman yang terinfeksi saat pengenalan patogen dan merupakan usaha tanaman untuk menghambat pertumbuhan patogen (Zhu et al. 2000). Uji hipersensitivitas pada tanaman tembakau merupakan tahap awal yang umum digunakan untuk mengetahui potensi patogenisitas suatu mikroba terhadap tanaman. Berdasarkan hasil uji HR ini, diduga 34 isolat tersebut memiliki potensi sebagai patogen tanaman sehingga tidak digunakan sebagai bahan percobaan berikutnya.

Uji patogenisitas pada tanaman padi dilakukan dengan cara melukai ujung daun padi yang akan diinokulasi. Pelukaan pada padi terjadi di alam antara lain akibat gesekan antara daun padi karena angin, gigitan binatang, atau kontak fisik dengan manusia. Luka akibat gesekan tersebut dapat menjadi lubang masuknya bakteri patogen ke dalam tanaman padi. Melalui luka tersebut, bakteri kemudian bergerak sambil memperbanyak diri menuju xilem. Bakteri juga dapat masuk pada tanaman padi melalui lubang alami seperti hidatoda, seperti cara Xoo menginfeksi daun padi (Ou 1985). Namun, infeksi bakteri lebih mudah terjadi melalui bagian daun yang terluka (Gnanamanickam et al. 1999). Pertimbangan penggunaan teknik pelukaan ini berdasar pada 
entry point yang efektif untuk proses infeksi Xoo. Diharapkan dengan cara ini selain diperoleh isolat bakteri filosfer yang memiliki kemampuan untuk menghambat perkembangan Xoo pada relung ekologi yang sama melalui mekanisme kompetisi (ruang dan nutrisi) dan atau antagonisme, diharapkan isolat tersebut juga mampu melindungi tanaman padi dari infeksi Xoo pada entry point-nya tanpa adanya kekhawatiran isolat itu sendiri akan menyebabkan penyakit pada tanaman padi.

Lebih dominannya kelompok bakteri gram positif yang diperoleh sesuai dengan hasil penelitian Zhang et al. (2010) dan Mwajita et al. (2013) yang menunjukkan bahwa komonitas mikroba filosfer mempunyai potensi fisiologis dan jumlah bakteri Gram positif yang tinggi dibandingkan bakteri Gram negatif. Keberadaan struktur endospora dan sifat aerobik dari ketiga isolat tersebut mengindikasikan bahwa ketiganya termasuk ke dalam kelompok Bacillus. Keberadaan kelompok Bacillus pada filosfer dalam persentase yang cukup besar juga telah dilaporkan dari filosfer tanaman padi (Mwajita et al. 2013).

\section{KESIMPULAN}

Sebanyak 285 isolat bakteri filosfer berhasil diisolasi dari tanaman padi varietas Ciherang umur 2.5 bulan yang berasal dari persawahan Situgede, Dramaga, Bogor. 58 isolat dari total isolat memiliki kemampuan menghasilkan senyawa bioaktif anti Xoo. Uji patogenisitas pada tanaman menunjukkan 18 isolat tidak berpotensi patogenik pada tanaman tembakau dan padi. Berdasarkan pewarnaan Gram terhadap 18 isolat tersebut, 14 isolat termasuk bakteri Gram positif, 4 bakteri Gram negatif, dan 5 diantaranya diduga Bacillus. Aktivitas penghambatan terhadap Xoo mengindikasikan adanya potensi kemampuan isolat-isolat tersebut sebagai agen pengendali hayati untuk Xoo yang merupakan penyebab penyakit hawar daun padi.

\section{UCAPAN TERIMA KASIH}

Penelitian ini dibiayai oleh Hibah Kompetensi DIKTI 2014. Oleh karena itu penulis mengucapkan terima kasih atas dukungan dana dan kepercayaan untuk melakukan penelitian ini.

\section{DAFTAR PUSTAKA}

Bertani G. 1951. Studies on lysogenesis. I. The mode of phage liberation by lysogenic Escherichia coli. J Bacteriol 62:293-300.

Dinh HD, Oanh NK, Toan ND, Van du P, Loan LC. 2008. Pathotype profile of Xanthomonas oryzae pv. oryzae isolates from the rice ecosystem in cuulong rever Delta. Omonrice
16:34-40.

Dowling DN, O'Gara F. 1994. Metabolites of Pseudomonas involved in the biocontrol of plant desease. Tibtech 12:133-141.

Downes FP, Ito K. 2001. Compendium of Methods for the Microbiological Examination of Foods. Washington D.C :American Public Health Association.

Gnanamanickam SS, Priyadarisini VB, Narayanan NN, Vasudevan P, Kavitha S. 1999. An overview of bacterial blight disease of rice and strategies for its management. Curr. Sci 77:1435-1443.

Hanarida I, Utami DW, Kadir TS, Koerniati S. 2007. Galur padi baru tahan hawar daun bakteri. Warta Penelitian dan Pengembangan Pertanian 20(1):5-6.

Hastuti DH, Lestari Y, Suwanto A, Saraswati R. 2012. Endophytic Streptomyces spp. as biocontrol agents of rice bacterial leaf blight pathogen (Xanthomonas oryzae pv. oryzae). Hayati 19(4): 155-162.

Inacio J, Pereira P, de Carvalho M, Fonseca A, AmaralCollaco MT, Martins IS. 2002. Estimation and diversity of phylloplane mycobiota on selected plants in a mediterraneantype ecosystem in Portugal. Microb. Ecol 44:344-353.

Lay BW. 1994. Analisis Mikrobiologi di Laboratorium. Jakarta :PT. Grafindo Persada.

Lindow SE, Brandl MT. 2003. Microbiology of the phyllosphere. Appl Environ Microbiol 69:1875.

Lisboa MP, Bonato D, Bizani D, Henriques JAP, Brandelli A. 2006. Characterization of bakteriosin-like substance produced by Bacillus amyloliquefaciens isolated from the Brazilian atlantic forest. Int Microbial 9:111-118.

Morris CE, Kinkel LL. 2002. Fifty years of phyllosphere microbiology: significant contributions to research in related fields. In: Phyllosphere Microbiology. (eds.) Lindow, S.E., E.I. Hecht-Poinar and V.J. Elliott. St Paul : APS Press.

Mwajita MR, Murage H, Tani A, Kahangi EM. 2013. Evaluation of rhizosphere, rhizoplane and phyllosphere bacteria and fungi isolated from rice in Kenya for plant growth promoters. SpringerPlus 2:606.

Ou, SH. 1985. Rice Disease. 2nd. England : Kiew Surrey.

Sudir, Nuryanto B, Kadir TS. 2012. Epidemiologi, patotipe, dan strategi pengendalian penyakit hawar daun bakteri pada tanaman padi. Iptek Tanaman Pangan 7(2): 79-87.

Thompson IP, Bailey MJ, FenlonFermor TR, Lilley AK, Lynch JM, McCormack PJ, McQuilken MP. 1993. Quantitative and qualitative seasonal changes in the microbial community from the phyllosphere of sugar beet (Beta vulgaris). Plant. Soil 150:177-191.

Wahyudi AT, Meliah S, Nawangsih AA. 2011. Xanthomonas oryzae pv. oryzae bakteri penyebab hawar daun pada padi: isolasi, karakterisasi, dan telaah mutagenesis dengan transposon. Makara Sains 15: 89-96.

Whipps JM, Hand P, Pink P, Bending GD. 2008. Phyllosphere microbiology with special reference to diversity and plant genotype. J Appl Microbiol 105:1744.

Zhang B, Bai Z, Hoefel D, Wang X, Zhang L, Li Z. 2010. Microbial diversity within the phyllosphere of different vegetable species. Formatex 1067-1077.

Zhu W, Magbanva MM, White FF. 2000. Identification of two novel hrp-associated genes in the hrp gene cluster of Xanthomonas oryzae pv.oryzae. J Bacteriol 182(7):18441853.

Zou LF, Wang XP, Xiang Y, Zhang B, Li YR, Xiao YL, Wang JS, Walmsley AR, Chen GY. 2006. Elucidation of the hrp clusters of Xanthomonas oryzae pv. oryzicola that control the hypersensitive response in nonhost tobacco and pathogenicity in susceptible host rice. Appl. Environ Microbiol 72:6212-6224. 